\title{
The Effect of Leaf Shredding on Apple Scab in South African Orchards
}

Saskia G. von Diest and Julia C. Meitz-Hopkins, Department of Plant Pathology, Stellenbosch University, Matieland 7602, South Africa; William E. MacHardy, Department of Plant Biology, University of New Hampshire, Durham; and Cheryl L. Lennox, Department of Plant Pathology, Stellenbosch University

\begin{abstract}
von Diest, S. G., Meitz-Hopkins, J. C., MacHardy, W. E., and Lennox, C. L. 2016. The effect of leaf shredding on apple scab in South African orchards. Plant Dis. 100:2094-2098.

The South African apple industry currently relies entirely on chemical fungicides to control apple scab (Venturia inaequalis). In this study, the effectiveness of sanitation strategies in reducing scab incidence and severity in South African orchards was evaluated. Over three seasons, leaf shredding with no fungicide sprays was tested against a nonsprayed, nonshredded negative control, a positive control that followed a commercial fungicide program, and a combined treatment of a commercial fungicide program with leaf shredding. Two treatment replicates were applied in a randomized block design in each of two orchards. Scab incidence and severity on fruit

and leaves were assessed weekly from green-tip until fruit-set in the following spring. Pooled data from the 3 years revealed that fruit scab incidence and severity and leaf scab severity $(51,55$, and $39 \%$, respectively, $P<0.05)$ and leaf scab incidence $(33 \%, P<0.1)$ were significantly lower in the leafshredding treatment than in the negative control. This is the first study to evaluate the effect of leaf shredding in reducing scab in South African orchards. Results indicate that this treatment is highly effective and should be integrated into scab management strategies in future, but should be customized to suit South African orchard conditions.
\end{abstract}

The South African apple industry is primarily export driven and reducing losses to apple scab, caused by Venturia inaequalis (Cooke) $\mathrm{G}$. Winter, is crucial to ensure profitable harvests, because cosmetic damage caused by scab reduces marketability of fruit. Various postharvest chemical fungicides have been tested against apple scab in South Africa over the past few decades (Schwabe and Heyns 1974; Schwabe and Matthee 1972). Tolerance or a decrease in sensitivity to certain chemical classes in local $V$. inaequalis populations has been found (Schwabe 1977, 1979; Schwabe and Shabi 1994; Schwabe and van der Rijst 1997). Although judicious use of fungicides against scab is recommended and is applied on most farms, the potentially harmful effect on human and animal health and the environment, especially when fungicides are not used according to recommendations, as well as residues on fruit of certain chemical classes, warrants the search for alternative strategies for scab control.

There is a direct, positive correlation between the amount of ascospore inoculum in spring and the incidence and severity of scab in summer (Holb 2006); therefore, treatment of leaf litter to reduce ascospore inoculum reduces the risk of disease and, subsequently, scab incidence and severity (Gadoury and MacHardy 1986). Removing the leaves from an orchard after leaf drop removes the potential source of primary inoculum for the following spring and has been shown to be an effective sanitation strategy against scab (Gomez et al. 2007; Holb 2006). Shredding the leaf litter has been reported to be comparably effective and more practical (Holb 2006; Sutton et al. 2000; Vincent et al. 2004). Urea has been tested as a postharvest chemical and sanitation strategy for scab control and, in overseas studies, $5 \%$ urea was effective in reducing ascospore discharge by 92 to $100 \%$ when leaves were dipped in urea, and by 32 to $97 \%$ when urea was sprayed onto trees in the previous autumn (Burchill 1968; Burchill et al. 1965; Carisse et al. 2000; Sutton et al. 2000; Vincent et al. 2004). In South Africa, urea was effective in reducing ascospore production significantly in the laboratory ( 89 to $99 \%$ ) but authors concluded that the percent reduction of ascospores in field trials (20 to $92 \%$ ) was inconsistent and too low to recommend using urea

Corresponding author: S. von Diest; E-mail: saskia@sun.ac.za

Accepted for publication 6 May 2016.

http://dx.doi.org/10.1094/PDIS-03-15-0294-RE

(C) 2016 The American Phytopathological Society as a postharvest treatment for scab (Schwabe and Heyns 1974; Schwabe et al. 1976). In one study, it was suggested that two applications of 5\% urea may have the desired eradicant effect, as opposed to a single application (Schwabe et al. 1976).

The objective of this study was to evaluate the effectiveness of sanitation strategies in reducing apple scab incidence and severity in South African apple orchards.

\section{Materials and Methods}

Experimental orchard details. Three Western Cape orchards were selected based on their history of high scab incidence (despite the high number of fungicide applications), their layout, and maintenance: weeds, grass and pruning material on orchard floors are cleared seasonally, and trees are pruned to keep tractor lanes clear, all of which allowed for easier application of sanitation treatments. Orchards A and B, in the Koue Bokkeveld were planted next to each other in 1996 with 'Fuji' on M793 rootstocks, with a tree spacing of 4 by $1.25 \mathrm{~m}$. Orchard C, in the Koue Bokkeveld, was planted in 1989 with 'Early Red One' on M793 rootstocks, with a tree spacing of 4.5 by $2 \mathrm{~m}$. Orchard D, in Elgin, was planted in 1994 with 'Braeburn' on seedling rootstocks, with a tree spacing of 4 by $1.2 \mathrm{~m}$.

Treatment description and application. In 2010, three postharvest sanitation practices (leaf removal, leaf shredding, and urea sprays) were applied once each in orchards A, B, and C. Leafremoval and leaf-shredding treatments were applied after $100 \%$ leaf drop in July 2010, due to delayed leaf drop in South Africa. For leaf removal, the leaves were manually raked from under the trees to the middle of the tractor lane and removed from the orchard. For leaf shredding, leaves were raked as for the leaf removal treatment and then shredded to a fine mulch in the tractor lane with a Nobili RM 155 triturator mulcher (Southtrade, Cape Town, South Africa), fitted with 012 universal composter blades. For the urea treatment, two separate applications of 5\% urea were applied at 70 and $100 \%$ leaf drop to leaf litter within the tree rows. Urea sprays were applied at 1,000 liters $\mathrm{ha}^{-1}$ with a tractor-drawn Hardi herbicide sprayer (Hardi Crop Protection SA Ltd., Cape Town, South Africa). A combined treatment of leaf shredding and urea was included to determine whether the combined effect of these treatments exceeded the effect of each treatment. Sanitation treatments were compared with a nonsanitized, nonsprayed negative control and to a nonsanitized positive control sprayed according to a commercial scab fungicide program. In the positive control, mancozeb, bupirimate, difenoconazole, cyprodinil, and dithianon were applied against scab in orchards A and B. 
Orchard D received the same spray schedule in the positive control, with the exception of bupirimate. The negative control did not receive any scab fungicides from postharvest in 2010 until December 2010 but other normal practices were applied (e.g., insect control, weed management, and pruning). The six treatments were replicated once in each trial orchard using a randomized block design, with each orchard treated as a block. Each treatment was applied over a minimum of five rows of trees, with the outer two rows of each treatment acting as a buffer zone of a minimum of $20 \mathrm{~m}$ to minimize ascospore movement and interference between treatments.

In 2011, due to practical and financial constraints, only the leafshredding treatment was repeated, based on the high potential it showed in reducing scab incidence and severity in the first season of the experiment. The size of the plots and number of orchards used for the trial were also reduced, with the trial only being conducted in orchards $\mathrm{C}$ and $\mathrm{D}$, but the number of replicates per treatment per orchard was increased to two. Four treatments were applied: a positive control, a leaf-shredding treatment, and a negative control as in 2010, and an additional combined treatment of leaf shredding with a standard scab fungicide spray program. Treatments with scab fungicide sprays received applications of mancozeb, cyprodinil, dithianon, and flusilazole in orchard C. Unfortunately, the full spray records of orchard D are missing. Treatments with leaf shredding were applied in July 2011 after 100\% leaf drop with a Nobili BNU 160 triturator mulcher, fitted with 01 universal blades. Raked leaves were shredded twice on the same day, to ensure that all leaves were shredded and shredded leaf pieces were sufficiently small. Each treatment was applied over five rows of trees, with the outer two rows of each treatment acting as a buffer zone of a minimum of $20 \mathrm{~m}$ to minimize ascospore interference between treatments.

The 2011 trial was repeated in 2012 and 2013. However, leaf shredding was applied using a Kverneland chopper (Kverneland South Africa, Pietermaritzburg, South Africa). In orchard C, mancozeb, cyprodinil, dithianon, difenoconazole, dodine, and flusilazole were applied against scab in the positive control and in the combined treatment in 2012 and 2013, with the addition of kresoxim-methyl in 2013. In orchard D, mancozeb, cyprodinil, dithianon, and fenarimol were applied in 2012 and mancozeb, bupirimate, and dithianon in 2013.

In 2013, a Nobili BNU 160 mulcher was used in orchard C and a Sicma mulcher (Rovic Leers, Cape Town, South Africa) with hammers in orchard D. Shredding was done twice on the same day and twice during the leaf-drop period, as opposed to twice on the same day and once during the leaf-drop period in 2011 and 2012.

Treatment evaluation using scab incidence and severity in spring. In 2010, treatment effect on scab incidence and severity on fruit and leaves in the subsequent season was evaluated in late November 2010 and February 2011. Scab lesions on 20 fruit and all leaves on six shoots on 10 trees in the middle row of five rows were counted. In spring 2011, 2012, and 2013, scab incidence and severity were assessed weekly from bud break until physiological fruit drop, regardless of ascospore discharge, and number of shoots assessed per tree was increased to 10 . Fruit and leaves were also assessed within 2 weeks of harvest in 2011,2012, and 2013. Scab incidence was calculated by dividing the number of fruit or leaves with at least one scab lesion by the number of fruit or leaves with no lesions and multiplying by 100 . Scab severity was determined by counting all the lesions on each fruit or leaf and assigning each fruit or leaf to a category. The equation from Kremer and Unterstenhöfer (1967) was used to calculate scab severity from these categories. Treatments were compared using a method modified from Holb (2006) that assessed scab incidence and severity in the subsequent season.

Statistical analysis. A two-way analysis of variance (ANOVA) was used to compare sanitation treatments in different weeks in experiment 1 using STATISTICA 11 data analysis software system (StatSoft, Inc.; www.statsoft.com). A mixed-model repeated-measures ANOVA was done to compare sanitation treatments in individual years, and also where data from 2011, 2012, and 2013 were pooled and weeks and years were included as main effects. A Pearson correlation was used to determine whether there was a relationship between scab incidence and severity on fruit and leaves for data pooled from 2011 to 2013.
A mixed-model repeated-measures ANOVA was done to compare sanitation treatments on airborne ascospores in experiment 2.1. Fisher's least significance difference $t$ test was used for posthoc testing. Significant differences were all evaluated on a 5\% significance level $(P<0.05)$.

\section{Results}

Treatment effect. ANOVA of the three-way interaction orchardtime of assessment-treatment indicated that the effects of time of assessment for the 2010-11 season and the orchards were not significant $(P>0.05$; data not shown); therefore, data from the three orchards (A, B, and C) in December 2010 and February 2011 were pooled. All measurements were significantly lower in the positive control than in the other five treatments. In the leaf-shredding treatment, fruit scab incidence and severity were significantly lower when compared with the negative control, while leaf scab incidence and severity did not differ significantly from the negative control. Leaf removal, urea sprays, and the combined treatment (leaf shredding with urea sprays) did not differ significantly from the negative control in any of the parameters measured $(P<0.05)$ (Table 1$)$.

When data for weeks 42 to 45 for fruit and weeks 41 to 45 for leaves in spring from 2011 to 2013 were pooled, ANOVA indicated a nonsignificant interaction: orchard-treatment for fruit scab incidence, fruit scab severity, leaf scab incidence, and leaf scab severity ( $P=0.25,0.44,0.64$, and 0.75 , respectively); therefore, data for the two separate orchards $C$ and $D$ could be pooled together for each of these parameters. Years 2011 and 2012, and 2011 and 2013, did not differ significantly from one another but 2012 and 2013 differed significantly from one another $(P=0.21,0.34$, and 0.03 , respectively). Leaf shredding significantly reduced fruit scab incidence and severity by 50.5 and $55.0 \%$, respectively, and leaf scab severity by $40.0 \%$ $(P>0.05)$ compared with the negative control but not leaf scab incidence $(33.3 \% ; P=0.06)$ (Table 2$)$. There was a strong positive correlation between scab incidence and severity on fruit and leaves $(r=$ 0.96 for both relationships). More detailed data for fruit scab incidence and severity data pooled from all weeks in each year are presented in Tables 3 and 4.

\section{Discussion}

In 2010 , leaf shredding was the only sanitation treatment that significantly lowered fruit scab incidence and severity when compared with the negative control (no fungicides or sanitation applied) (i.e., $11.5 \%$ lower incidence and $26.6 \%$ lower severity on scabbed fruit, respectively). Combining urea sprays with leaf shredding did not improve on the effect of leaf shredding alone on fruit or leaf scab incidence, which is similar to results reported by Sutton et al. (2000).

Scab incidence and severity in the urea treatment was higher than but did not differ significantly from the negative control. These results are not consistent with published studies that have been conducted on urea as a postharvest scab eradicant (Burchill 1968; Sutton et al. 2000; Vincent et al. 2004) but are in agreement with previous studies in the Western Cape (Schwabe and Heyns 1974;

Table 1. Pooled data of scab incidence and severity on fruit and leaves in orchards A, B, and C in Koue Bokkeveld, assessed in early summer (December 2010) and shortly before harvest (February 2011)y

\begin{tabular}{lccccc}
\hline & \multicolumn{2}{c}{ Fruit } & & \multicolumn{2}{c}{ Leaf } \\
\cline { 2 - 3 } \cline { 6 - 6 } Treatment $^{\mathbf{z}}$ & Incid & Sev & & Incid & Sev \\
\hline Positive control & $5.2 \mathrm{a}$ & $0.6 \mathrm{a}$ & & $1.7 \mathrm{a}$ & $0.2 \mathrm{a}$ \\
Leaf removal & $94 \mathrm{bc}$ & $56 \mathrm{bc}$ & & $40 \mathrm{bc}$ & $16 \mathrm{~b}$ \\
Leaf shredding & $85 \mathrm{~b}$ & $47 \mathrm{~b}$ & & $38 \mathrm{~b}$ & $15 \mathrm{~b}$ \\
2x urea sprays & $98 \mathrm{c}$ & $68 \mathrm{c}$ & & $45 \mathrm{c}$ & $18 \mathrm{~b}$ \\
Leaf shredding and urea & $88 \mathrm{bc}$ & $52 \mathrm{bc}$ & & $40 \mathrm{bc}$ & $15 \mathrm{~b}$ \\
Negative control & $96 \mathrm{c}$ & $64 \mathrm{c}$ & & $44 \mathrm{bc}$ & $18 \mathrm{~b}$ \\
\hline
\end{tabular}

y Incidence (Incid) is defined as percentage of fruit or leaves with at least one lesion. Severity (Sev) is defined as percentage of fruit or leaf area visibly affected by scab. Means with the same letter in a column are not significantly different $(P<0.05)$

${ }^{\mathrm{z}}$ Positive control $=$ full scab fungicide program and negative control $=$ no scab fungicides or sanitation. 
Schwabe and Matthee 1972; Schwabe et al. 1976) and in Ireland (Mac an tSaoir et al. 2010). Leben and Keitt (1948) found that urea was one of the four most favorable nitrogen sources for $V$. inaequalis. Urea applied as a scab sanitation treatment aims to stimulate microbial growth on leaves to compete with and inhibit $V$. inaequalis pseudothecial formation (Carisse and Dewdney 2002; Sutton et al. 2000). It may be possible that the double application of 5\% urea to leaf litter in this study stimulated rather than inhibited the sexual stage of $V$. inaequalis in the urea treatment plots. This may have caused a higher pseudothecial density per fertile lesion and ascospore dose, and may explain the higher scab levels found in those treatment plots.

Burchill (1968) found that urea applications more than a week before leaf drop significantly reduced the efficacy of the treatment. During long leaf-drop periods that are typical under South African conditions, the use of defoliants to shorten leaf-drop periods should be investigated in combination with urea sprays. Additionally, Sutton et al. (2000) reported that ascospore productivity was lower $(66 \%)$ when $5 \%$ urea was applied shortly before bud break. This should be tested in future studies in South Africa, in combination with defoliant sprays, to determine whether the amount of time between urea spray application and leaf abscission can be reduced to less than a week, which would increase efficacy of urea as a sanitation treatment.

Leaf removal equates to inoculum removal, because $V$. inaequalis uses only fallen apple leaves as substrate for winter survival in regions where asexual inoculum of $V$. inaequalis does not remain viable throughout winter on the tree. The scab levels in the leaf-removal treatments in 2010 did not correspond with what was expected,

Table 2. Pooled data for mean fruit and leaf scab incidence and severity in October and early November in 2011, 2012, and 2013 in orchard C (Koue Bokkeveld) and orchard D (Elgin) ${ }^{\mathrm{w}}$

\begin{tabular}{lccccc}
\hline & \multicolumn{2}{c}{ Fruit $^{\mathbf{x}}$} & & \multicolumn{2}{c}{ Leaf $^{\mathbf{y}}$} \\
\cline { 2 - 3 } \cline { 6 - 6 } Treatment $^{\mathbf{z}}$ & Incidence $^{n}$ & Severity & & Incidence & Severity \\
\hline PC & $1.9 \mathrm{a}$ & $0.5 \mathrm{a}$ & & $1.2 \mathrm{a}$ & $0.3 \mathrm{a}$ \\
$\mathrm{LS}+\mathrm{PC}$ & $2.4 \mathrm{a}$ & $0.5 \mathrm{a}$ & & $1.0 \mathrm{a}$ & $0.3 \mathrm{a}$ \\
$\mathrm{LS}$ & $15.2 \mathrm{~b}$ & $4.5 \mathrm{~b}$ & & $8.4 \mathrm{~b}$ & $3.6 \mathrm{a}$ \\
NC & $30.7 \mathrm{c}$ & $10.0 \mathrm{c}$ & & $12.6 \mathrm{~b}$ & $6.0 \mathrm{~b}$ \\
\hline
\end{tabular}

${ }^{\mathrm{w}}$ Incidence is defined as percentage of fruit or leaves with at least one lesion. Severity is defined as percentage of fruit or leaf area visibly affected by scab. Means with the same letter in a column are not significantly different $(P<0.05)$

${ }^{x}$ Fruit data from week 42 (during bloom) until week 45 (physiological fruit thinning).

y Leaf data from week 41 (bud break) until week 45 (physiological fruit thinning).

z $\mathrm{PC}$ (positive control) $=$ full scab fungicide program, $\mathrm{LS}+\mathrm{PC}=$ full scab fungicide program and leaf shredding, LS = only leaf shredding, and NC (negative control) $=$ no scab fungicides or sanitation.

Table 3. Mean scab incidence as percentage of fruit with at least one lesion from weeks 42 to 45 (October and early November) in 2011, 2012, and 2013 in orchard C (Koue Bokkeveld) and orchard D (Elgin)

\begin{tabular}{|c|c|c|c|c|c|c|}
\hline \multirow[b]{3}{*}{ Treatment $^{\mathrm{z}}$} & \multicolumn{6}{|c|}{ Year, orchard ${ }^{y}$} \\
\hline & \multicolumn{2}{|c|}{2011} & \multicolumn{2}{|c|}{2012} & \multicolumn{2}{|c|}{2013} \\
\hline & $\mathbf{C}$ & D & $\mathbf{C}$ & D & $\mathbf{C}$ & D \\
\hline $\mathrm{PC}$ & $0.1 \mathrm{a}$ & $11 \mathrm{a}$ & $0.3 \mathrm{a}$ & $0.7 \mathrm{a}$ & $2.1 \mathrm{a}$ & $0 \mathrm{a}$ \\
\hline $\mathrm{LS}+\mathrm{PC}$ & $0 \mathrm{a}$ & $9.7 \mathrm{a}$ & $0.3 \mathrm{a}$ & $0.8 \mathrm{a}$ & $1.6 \mathrm{a}$ & $0 \mathrm{a}$ \\
\hline LS & $5.2 \mathrm{~b}$ & $16.9 \mathrm{~b}$ & $35.6 \mathrm{~b}$ & $11.9 \mathrm{~b}$ & $14 \mathrm{ab}$ & $6.1 \mathrm{~b}$ \\
\hline $\mathrm{NC}$ & $15.2 \mathrm{c}$ & $31.1 \mathrm{c}$ & $70 \mathrm{c}$ & $14.8 \mathrm{~b}$ & $22.2 \mathrm{~b}$ & $27.8 \mathrm{c}$ \\
\hline
\end{tabular}

y Means with the same letter in a column are not significantly different $(P<$ $0.05)$.

${ }^{\mathrm{z}} \mathrm{PC}($ positive control $)=$ full scab fungicide program applied, $\mathrm{LS}+\mathrm{PC}=$ full scab fungicide program and leaf shredding applied, LS (leaf shredding) $=$ only leaf shredding applied, and NC (negative control) $=$ no scab fungicides or sanitation applied. considering that a high percentage of leaves were removed (estimated $99 \%$ ) in this study. Very few scab infections were seen in the treatment plots during late October 2010 and scab assessments did not begin until late November 2010, when trees were at physiological fruit-drop stage. However, the sanitation treatment plots were severely infected, as was the case in 2011 and 2012. Louw (1951) observed the first scab lesions (three lesions per 100 leaves) in early October in the Koue Bokkeveld, and the next scab observation was only in late October on the calyx leaves of recently set fruit, when lesions were "only just macroscopically discernible". The author also reported that the first conidia were found on slides hung in tree canopies for the first time on 20 October; therefore, scab lesions that were observable in November would have included lesions caused by ascospores and conidia. Therefore, timing of observation of the first scab lesions in 2010 in this study corresponds with results reported by Louw (1951). Thus, although the data in this study indicate that the effect of leaf shredding was effective until late spring, the data are not representative of the effect the sanitation treatments had on scab incidences and severity caused by early spring primary infections, because they would have included lesions caused by conidial infections. Because sanitation of leaf litter aims to reduce ascospores for the following season, the scab lesions that develop from the earliest primary infection are the best indicator of sanitation efficacy, before lesions produce conidia that cause secondary infections. The effect of sanitation treatments becomes less evident as scab builds up from each secondary infection period due to the addition of conidial inoculum. The late timing of the scab assessment in 2010 obscured the true effect of all treatments (including leaf removal) in reducing primary infections in spring. Leaf removal in commercial orchards in South Africa would be impractical, due to the sheer volume of leaf material that drops in autumn and the large size and number of South African orchards; therefore, it is unlikely that this treatment would be appropriate for use in South African orchards.

Data pooled from 2011, 2012, and 2013 indicated that leaf shredding significantly reduced fruit scab incidence and severity and leaf scab severity $(50.5,55.0$, and $40.0 \%$, respectively) compared with the negative control, but not leaf scab incidence (33.3\%) (Table 2). However, the $P$ value of the treatment difference in leaf scab incidence indicates a trend in lower leaf scab incidence in the leaf-shredding treatment compared with the negative control. These results are similar to the reductions of 46 and $65 \%$ in fruit and leaf scab incidence, respectively, reported by Sutton et al. (2000).

There are several reasons why the efficacy of shredding leaves may vary. Poorly managed weeds and tall grass in the tractor drive row can be associated with fewer leaves being shredded and pieces of shredded leaves being larger, thus increasing the variability of effects of leaf shredding between orchards, lowering the percentage of leaf shredding (which directly affects the efficacy of the treatment), and decreasing the overall effect of leaf shredding (Sutton et al. 2000). Pruning material on the orchard floor made raking the leaf litter very difficult in 2010 and 2011; consequently, not all leaf litter

Table 4. Mean scab severity as percentage of fruit or leaf area visibly affected by scab from weeks 42 to 45 (October and early November) in 2011, 2012, and 2013 in orchard C (Koue Bokkeveld) and orchard D (Elgin)

\begin{tabular}{|c|c|c|c|c|c|c|}
\hline \multirow[b]{3}{*}{ Treatment $^{\mathrm{z}}$} & \multicolumn{6}{|c|}{ Year, orchard } \\
\hline & \multicolumn{2}{|c|}{2011} & \multicolumn{2}{|c|}{2012} & \multicolumn{2}{|c|}{2013} \\
\hline & C & D & C & D & C & D \\
\hline PC & $0.1 \mathrm{a}$ & $3.2 \mathrm{a}$ & $0.1 \mathrm{a}$ & $0.3 \mathrm{a}$ & $0 \mathrm{a}$ & $0.5 \mathrm{a}$ \\
\hline $\mathrm{LS}+\mathrm{PC}$ & $0 \mathrm{a}$ & $3 \mathrm{a}$ & $0.1 \mathrm{a}$ & $0.2 \mathrm{a}$ & $0 \mathrm{a}$ & $0.4 \mathrm{a}$ \\
\hline LS & $1.9 \mathrm{ab}$ & $5.2 \mathrm{~b}$ & $10.1 \mathrm{~b}$ & $4.7 \mathrm{~b}$ & $1.3 \mathrm{a}$ & $4 \mathrm{~b}$ \\
\hline $\mathrm{NC}$ & $3.9 \mathrm{~b}$ & $9.2 \mathrm{c}$ & $25.1 \mathrm{c}$ & $5 \mathrm{~b}$ & $8.4 \mathrm{~b}$ & $8.1 \mathrm{c}$ \\
\hline
\end{tabular}

y Means with the same letter in a column are not significantly different $(P<$ $0.05)$.

${ }^{\mathrm{z}} \mathrm{PC}($ positive control $)=$ full scab fungicide program applied, $\mathrm{LS}+\mathrm{PC}=$ full scab fungicide program and leaf shredding applied, LS (leaf shredding) $=$ only leaf shredding applied, and NC (negative control) $=$ no scab fungicides or sanitation applied. 
may have been raked to the middle of the tractor lane and shredded as intended. There were also a limited number of dry periods in winter long enough for leaves to dry and be raked efficiently for shredding, because both regions are winter rainfall regions (Mediterranean climate) of the Western Cape. For these two reasons, it is highly likely that pseudothecia formed on leaves that fell earlier and that the late timing of leaf shredding in both regions could not prevent pseudothecial formation.

The strong positive correlation $(r=0.96)$ between incidence and severity on both fruit and leaves agrees with previous studies (Holb et al. 2003; Jeger 1981). Considering that assessing leaf scab severity is considerably more time consuming and less accurate than assessing leaf scab incidence (Holb et al. 2003) and the strong positive correlation between incidence and severity and scab development in spring, this study strongly supports the recommendation to assess fruit and leaf scab incidence in autumn, as is done for potential ascospore dose calculations (MacHardy 2000).

Jeger (1984) reported that scab severity did not affect the number or maturity of pseudothecia that developed on scabbed leaves, but he did state that "late infections on abaxial surfaces are important in that they are much more difficult to observe in conventional disease assessments and the grower or advisor may be lulled into a false sense of security by an apparent absence of scab at leaf-fall". Thus, shredding the leaf litter has the added feature of reducing pseudothecial development from lesions on the abaxial surface. This reduces the risk of an unexpected scab buildup due to infections that may occur from ascospores produced on the under-surface of the leaf.

Scab lesions were observed earlier in orchard D in Elgin than in orchard C in Koue Bokkeveld, which agrees with reports by Louw (1951). The higher rainfall in Elgin in September and October 2011, 2012, and 2013 (which is more conducive for V. inaequalis infections) (Schwabe 1980) may have contributed to a more noticeable earlier buildup of scab.

Fruit scab incidence and severity in the leaf-shredding treatment was significantly lower than the negative control shortly before harvest for the first three seasons (2010, 2011, and 2012), except for orchard D for the third season (February 2013). Apple scab is a polycyclic disease and, usually, as soon as conidia are dispersed in spring, the disease increases at an exponential rate if unchecked (Holb et al. 2004; Sutton et al. 1976). However, van der Plank (1963) described how the onset of disease in a sanitized area is later and final disease levels at the end of a season are often less than in nonsanitized areas, provided that a sufficient reduction in inoculum occurred before the season began. Therefore, the significant reduction in initial inoculum in leaf-shredding plots may have prevented scab levels from increasing as quickly as in negative control plots throughout the season, and may explain the reductions in scabbed fruit shortly before harvest.

The effects of leaf shredding on airborne ascospores and on leaflitter density were also tested, although technical problems meant that results from those experiments could not be statistically analyzed and, therefore, are not presented.

In conclusion, leaf shredding was significantly effective as a postharvest sanitation treatment in reducing fruit and leaf scab over 4 years. However, efficacy of leaf shredding in reducing scab inoculum and disease levels in orchards varies and relies on a number of factors. One of the most important factors is timing, because the longer the delay in shredding after leaf drop, the greater the opportunity for fertilization and pseudothecial formation, which directly affects the efficacy of the treatment. Delayed leaf drop, especially in warm winter regions (e.g., Elgin), means that leaf drop occurs over up to 2 months, and results suggest that shredding more than once over the period of leaf drop will increase efficacy, as was shown in the airborne ascospore-trapping experiment. Ridges in orchards and rocky soils, wet winters affecting when leaf shredding can be applied, and lack of equipment suited to South African orchards are also important factors that must be addressed because they have been shown to lower shredding efficacy. Developing shredding machines better suited for South Africa orchard characteristics and conditions would increase the efficacy of this sanitation practice.
Leaf shredding could become widely adopted in the South African apple industry, if it were optimized for local orchard conditions. However, more studies are needed, specifically to compare urea sprays shortly before bud break with shredding twice during the leaf-drop period. This could aid the South African apple industry in remaining competitive for export markets and remaining highly profitable.

\section{Acknowledgments}

We thank the South African apple growers for participating in this study, and Hortgro Science and the National Research Foundation (THRIP) for funding the project.

\section{Literature Cited}

Burchill, R. T. 1968. Field and laboratory studies on the effect of urea on ascospore production of Venturia inaequalis (Cke.) Wint. Ann. Appl. Biol. 62:297-307.

Burchill, R. T., Hutton, J. E., Crosse, J. E., and Garrett, C. M. E. 1965. Inhibition of the perfect stage of Venturia inaequalis (Cooke) Wint. by urea. Nature 205: 520-521.

Carisse, O., and Dewdney, M. 2002. A review of non-fungicidal approaches for the control of apple scab. Phytoprotection 83:1-29.

Carisse, O., Philion, V., Rolland, D., and Bernier, J. 2000. Effect of fall application of fungal antagonists on spring ascospore production of the apple scab pathogen, Venturia inaequalis. Phytopathology 90:31-37.

Gadoury, D. M., and MacHardy, W. E. 1986. Forecasting ascospore dose of Venturia inaequalis in commercial apple orchards. Phytopathology 76:112-118.

Gomez, C., Brun, L., Chauffour, D., and De La Vallée, D. 2007. Effect of leaf litter management on scab development in an organic apple orchard. Agric. Ecosyst. Environ. 118:249-255.

Holb, I. J. 2006. Effects of six sanitation treatments on leaf litter density, ascospore production of Venturia inaequalis and scab incidence in integrated and organic apple orchards. Eur. J. Plant Pathol. 115:293-307.

Holb, I. J., de Jong, P. F., and Heijne, B. 2003. Summer epidemics of apple scab: The relationship between measurements and their implications for the development of predictive models and threshold levels under different disease control regimes. J. Phytopathol. 151:335-343.

Holb, I. J., Heijne, B., Withagen, J. C. M., and Jeger, M. J. 2004. Dispersal of Venturia inaequalis ascospores and disease gradients from a defined source. Phytopathology 152:639-646.

Jeger, M. J. 1981. Disease measurement in a study of apple scab epidemics. Ann. Appl. Biol. 99:43-51.

Jeger, M. J. 1984. Overwintering of Venturia inaequalis in relation to lesion intensity on leaf surfaces, and leaf surface exposed. Trans. Br. Mycol. Soc. 83:495-500.

Kremer, F. W., and Unterstenhöfer, G. 1967. Computation of results of crop protection experiments by the method of Townsend and Heuberger. HöfchenBriefe Bayer Pflanzenschutz Nachr. 20:625-628.

Leben, C., and Keitt, G. W. 1948. Venturia inaequalis (Cke.) Wint. V. The influence of carbon and nitrogen sources and vitamins on growth in vitro. Am. J. Bot. 35:337-343.

Louw, A. J. 1951. Studies on the influence of environmental factors on the overwintering and epiphytology of apple scab [Venturia inaequalis (Cke.) Wint.] in the winter-rainfall area of the Cape Province. Sci. Bull. Dep. Agric. S. Afr. 310:1-48.

Mac an tSaoir, S., Cooke, L. R., and McCracken, A. R. 2010. The effects of leaf litter treatments, post-harvest urea and omission of early season fungicide sprays on the overwintering of apple scab on Bramley's Seedling grown in a maritime environment. Irish J. Agric. Food Res. 49:55-66.

MacHardy, W. E. 2000. Action thresholds for managing apple scab with fungicides and sanitation. International Conference on Integrated Fruit Production, 2000. Acta Hortic. 525:123-132.

Schwabe, W. F. S. 1977. Tolerance of Venturia inaequalis to benzamidazole fungicides and dodine in South African orchards. Phytophylactica 9: 47-54.

Schwabe, W. F. S. 1979. Resistance of the apple scab fungus (Venturia inaequalis) to benzamidazole fungicides. Deciduous Fruit Grow. 29: 418-422.

Schwabe, W. F. S. 1980. Epidemiology and control of apple scab in South Africa. Ph.D. dissertation, Stellenbosch University, Matieland, South Africa.

Schwabe, W. F. S., and Heyns, A. J. 1974. Beheer van appelskurfsiekte (Venturia inaequalis) deur na-oestoediening van swamdoders. Tegniese mededeling no. 121. Departement van Landbou-Tegniese Dienste, Pretoria, South Africa.

Schwabe, W. F. S., and Matthee, F. N. 1972. Fusicladium: Can urea eradicate the primary infection source? Deciduous Fruit Grow. 22:179-181.

Schwabe, W. F. S., Matthee, F. N., and van Blerk, E. 1976. Fusicladium Eradication of the primary infection source II. Deciduous Fruit Grow. 26 $352-358$ 
Schwabe, W. F. S., and Shabi, E. 1994. Tolerance of Venturia inaequalis to ergosterol biosynthesis inhibiting fungicides in South Africa. Nor. J. Agric. Sci. Suppl. 17:171-172.

Schwabe, W. F. S., and van der Rijst, M. 1997. Tolerance of Venturia inaequalis to ergosterol biosynthesis inhibiting fungicides in South African commercial apple orchards. Deciduous Fruit Grow. 47:303-307.

Sutton, D. K., MacHardy, W. E., and Lord, W. G. 2000. Effects of shredding or treating apple leaf litter with urea on ascospore dose of Venturia inaequalis and disease build-up. Plant Dis. 84:1319-1326.
Sutton, T. B., Jones, A. L., and Nelson, L. A. 1976. Factors affecting dispersal of conidia of the apple scab fungus. Phytopathology 66:1313-1317.

Van der Plank, J. E. 1963. Sanitation with special reference to potato blight Pages 122-136 in: Plant Diseases: Epidemics and Control. Academic Press, London.

Vincent, C., Rancourt, B., and Carisse, O. 2004. Apple leaf shredding as a nonchemical tool to manage apple scab and spotted tentiform leafminer. Agric. Ecosyst. Environ. 104:595-604 